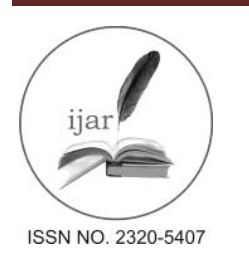

\author{
Journal homepage: http://www.journalijar.com \\ Journal DOI: $10.21474 /$ IJAR01
}

RESEARCH ARTICLE

\title{
INCLUSIVE UNIVERSITY: A WAY OUT TO ENSURE QUALITY, EQUITY, AND ACCESSIBILITY FOR STUDENTS WITH DISABILITIES IN HIGHER EDUCATION.
}

\author{
Ratan Sarkar. \\ Research Scholar, Ramakrishna Mission Vivekananda University, Faculty of Disability Management and Special \\ Education, Coimbatore-641020, Tamil Nadu.
}

\section{Manuscript Info}

Manuscript History:

Received: 14 February 2016

Final Accepted: 18 March 2016

Published Online: April 2016

Key words:

Inclusive University, Higher Education, Quality, Equality, Accessibility, \& Students with Disabilities.

*Corresponding Author

Ratan Sarkar.

\section{Abstract}

The present era is best known as the era of inclusion. In this era one of the most important goals of higher educational institutes is to impart quality education among one and all regardless any discrimination on any grounds in order to envisage the path of building a completely just and inclusive society. Government of India has undertaken numbers of initiatives by framing various acts, legislations, and launching schemes, and starting programmes to ensure quality, equity and accessibility in higher education (HE) for students with disabilities. However, research reveals that out of 722 Indian universities (Current as of $30^{\text {th }}$ June 2015) not even a single one is completely disabled friendly. Research also revealed that only $0.1 \%$ students with disabilities are in mainstream educational institutions at the university level (N.C.P.E.D.P., 2004). A student with a disability studying in mainstream educational institutions at university level in India experiences many difficulties in navigating through the obstacle course of the Indian educational system. Problems exist in many areas - course content, trained staff facilities, accessible environment, social stigma, negative attitudes, resources, educational policy, legislations, and schemes, assistive technology and devices as well as the examination and evaluation process. The relative physical inaccessibility of educational institutions, unavailability of accessible content in different forms, lack of trained and sensitive teachers, and the lack of awareness about developments in enabling technologies have hitherto rendered the educational environment itself rather difficult to access. Thus the educational experience at university level often becomes a nightmare for a student with disability. In this regard the need of restructuring university at inclusive line cannot be denied as it is premised on the guiding principle to promote quality, equity, accessibility, student success, and high-quality learning. An inclusive university refers to a stimulating study environment where the student's individual competence is taken into account and is allowed to develop. A university where respect, loyalty and a positive outlook on people characterize work and relations. By making inclusive university universities can achieve excellence in learning, teaching, student development, institutional functioning, and engagement in local and global communities. However, a high-quality, practical liberal education system must be made possible for all students with disabilities through inclusive university in India in order to achieve the excellence in HE. The present paper is an attempt to highlight the need of restructuring the university in inclusive line. This paper also suggests steps to be taken to create inclusive environment at university considering various existing challenges experienced by the students with disabilities. 


\section{Introduction:-}

The Indian Higher Education system is said to be the world's third largest, preceded by the ones in United States and China. However, higher education (HE) in India, in itself stands for a great contradiction. On one side, India ranks among the best education providing countries in the world and on the other there is not even a single university with proper infrastructure capable to meet the basic educational needs of students with disabilities in India. In the midst of all these problems India is working towards ensuring equal access and education for all. Disability is one of many factors that lead persons towards marginalization and exclusion in almost all the aspects of life, especially in education. In 1994, the United Nations re-emphasized the need for states to recognize the right of people with disabilities to education (UNESCO 1994). Similarly, within the Indian Constitution it is mentioned that providing education to all citizens without making discrimination on any grounds is the joint responsibility of the central and state governments. Government of India has come up with the reservation policy in higher educational institutes for persons with disabilities to ensure equal educational opportunities. Being a signatory to The United Nations Convention on Rights of Persons with Disabilities (UNCRPD, 2006) and The Universal Declaration of Human Rights (UDHR, 1948) India is also committed to bring the person with disabilities to the mainstream ensuring their human rights. In addition, in the twenty first century which is regarded as an era of inclusion and knowledge one of the most important goals of higher educational institutes is to impart quality education among one and all regardless any discrimination on the grounds of age, caste, creed, socio-economic background, gender, disability, ethnicity, religion or other belief in order to envisage the path of building a completely just and inclusive society. Government of India has also undertaken numbers of initiatives by framing various acts and legislations, and launching schemes, and starting programmes to ensure quality, equity and accessibility in HE for students with disabilities. However, these declarations, initiatives, policies, and alike may be very good on paper but the biggest test is in their applicability in real life situations.

\section{Understanding Inclusion and Inclusive Education:-}

Inclusion is a difficult concept to describe because how it is defined and implemented tends to be context specific (Armstrong et al., 2011; Lambe 2011). This variability of the concept and its conceptualization can lead to it "meaning everything and nothing at the same time" (Armstrong et al., 2011). However, it is defined broadly as a philosophy informing educational planning, provisioning and resourcing, a definition that prioritizes diversity and how education institutions respond to that (Armstrong et al., 2011). In India, inclusive education is a human right which refers to embracing all without excluding any one whosoever. It addresses the learning and other needs of every one. It lays much emphasis to include those who are vulnerable to marginalization and exclusion. It implies that all learners with or without disabilities are able to learn together in an inclusive and enabling environment. Inclusive education celebrates the diversity as richness. Inclusive education as a notion seeks to develop a just and humane society, a value that resonates with the Constitution. It is also concerned with the creation of a quality education system, which, if coupled with access, makes the core of what Akoojee and Nkomo (2007) regard as a successfully transformed HE. The adoption of an inclusive education and training system is a significant reflection of the both social and human right model in action.

\section{What is Inclusive University?}

An inclusive university refers to a stimulating study environment where the student's individual competence is taken into account and is allowed to develop. A university where respect, loyalty and a positive outlook on people characterize work and relations. An environment where an open dialogue between students with different backgrounds, perspectives and competence is what lays the foundation for learning, creative energy and development. A university where discrimination on any grounds, offensive behavior and harassment are never allowed. Inclusive university is what helps to promote equal rights and opportunities for students with disabilities and integrate diversity, equity, and educational quality and practices democratic culture. Making inclusive university is an active process through which universities can achieve excellence in learning, teaching, student development, institutional functioning, and engagement in local and global communities. One of the corner stones in the effort to promote an inclusive university is that our university lives up to the requirements of discrimination legislation and thus, the effort to actively work with preventative measures to combat discrimination, and promote equal rights and opportunities for students and employees regardless of age, social background, sexual orientation, gender, disability, ethnicity, religion or other belief. 


\section{Need of Restructuring the University in Inclusive Line:-}

Moving toward a university model based on the principles of inclusive education is a challenge for HE. One needs only to look back a decade to see that the reality in today's classrooms is much different than before. The explanation for this change cannot be sought only in terms of differences in today's students, but also in the transformations that have taken place over years in areas like technology advancement and integration in teachinglearning process, students-teacher ratio, teaching-learning approaches, policies and legislations, societal needs, etc. In addition, what attracts one's attention is a more diversified student body in the classrooms with different nationalities, ages, cultures, economic status, abilities, disabilities, and other traits. As this growing diversity in the classroom becomes more prominent, more and more researchers are looking at how HE is responding to students with different abilities, or as they are usually called, students with disabilities. In fact, it is a proven reality that the number of university students with disabilities is slowly increasing (Debram \& Salzberg 2005). This increase in student with disabilities in university classrooms has doubtlessly been influenced by declarations and regulations passed over the past few years. In 1998, the UNESCO World Declaration on Higher Education, based on the Universal Declaration of Human Rights (WHO, 2001), forged a new vision of HE, which underscores the right of every person to an education and equal rights of access to higher studies for all, and the Convention on the Rights of Persons with Disabilities (UN, 2006) stated that persons with disabilities must be ensured access to HE, professional training, adult education and life-long learning. However, the existence of such declarations and legislation are not enough to guarantee the right of these students to a non-discriminatory quality education and based on the principles of inclusive education. In this perspective, many scholars (Fuller, Bradley, \& Healey, 2004; Tomlinson, 1996) claim the need for HE to be inclusive, and its responsibility for responding to the needs of the entire student body. These scholars also suggest that inclusion in HE is advisable not just in terms of social or ethical fairness, but also because it represents a benefit to the institution, in the belief that improvements made for students with disabilities will benefit the rest of the students as well, and thereby contribute to building a better university (Ferni \& Henning, 2006). Therefore, promoting an inclusive environment in universities and reducing the barriers those students with disabilities come up against in teaching, learning and evaluation is the best way to explain and respond to their needs.

\section{Status of Mainstream Education of Students with Disabilities (SWDs) in Universities:-}

National Centre for Promotion of Employment for Disabled People (N.C.P.E.D.P., 2004) conducted a survey on 322 Universities in India to know the status of mainstream education of students with disabilities. A total of 119 (36.9\%)

Universities responded (Source: http://ncpedp.org/eductn/ed-resrch.htm).

* In the total of 119 respondent Universities, only $\mathbf{1 , 6 3 5}$ students with disabilities are enrolled. Therefore, only about $0.1 \%$ of the students were found to be those with disabilities. While $3 \%$ seats in educational institutions are to be reserved for students with disabilities, the figure of $0.1 \%$ is nowhere close to this figure.

* In all the 119 respondent Universities, only $\mathbf{1 , 2 0 3}$ students with orthopaedic impairments were enrolled. Furthermore, only 18 Universities (15\%) reported that they provided appropriate desks and chairs for students with disabilities, only $11(9 \%)$ provided wheelchairs and only $9(7.5 \%)$ of them provided access to tricycles. Therefore, it evident those only persons with minor physical impairments, who required minimum physical assistance of any kind, got admission in the Universities.

* In all the 119 Universities, only 311 students with visual impairments were enrolled. While only 16 Universities had special computer software, only $10(8.4 \%)$ Universities provided access to books in Braille.

* In all the 119 Universities, only 38 students with hearing impairments study. Only $9(7.5 \%)$ Universities reported provision of hearing aids for students while 10 (8.4\%) of them provided sign language interpreters. Even these figures seem exaggerated as on further investigation one University reported that the sign language interpreters were not provided in classrooms, but arranged for during certain seminars/conferences. Only 11 Universities had students with hearing impairment. Most of these had just one such student except Osmania University (Hyderabad) that had 23 of total of 38 students with hearing disability.

* In all the 119 Universities, only 22 students with mental disability were enrolled. Assuming that people with intellectual impairment were unlikely to reach the HE level, the $1.3 \%$ of students with mental disability in the Universities was likely to be students with mental illness. It was very clear that awareness about the abilities of persons with intellectual impairment and mental illness was lacking.

* Seven Universities (5.8\%) categorically mentioned that they do not admit students with disability, conveniently ignoring the law. 
* About 24 Universities (20\%) clearly reported that they did not follow the 3\% reservation for students with disabilities as mandated by the law of the nation. While the Persons with Disabilities (Equal Opportunities, Protection of Rights and Full Participation) Act, 1995 mandates a wide variety of efforts to ensure equal opportunities to students with disabilities for getting quality education, it also clearly states that 'all Government educational institutions and other educational institutions receiving aid from the Government, shall reserve not less than 3\% seats for persons with disabilities.'

* About $\mathbf{7 6 . 3 \%}$ of the disabled students were males, while $23.7 \%$ were females. The government focus on educating girls did not seem to have much impact on the education level of girls with disabilities.

* Osmania University (Hyderabad) was the only one that projected a healthier trend in giving opportunities to students with different disabilities - out of its total number of 60 students with disabilities, 13 had orthopaedic disabilities, 3 visual disability, 23 hearing disability and 21 had mental disabilities.

* Banaras Hindu University (U.P.) and Aligarh Muslim University (U.P.) had the number of disabled students in three digits - 208 and 202 respectively. 38 Universities (31\%) had no students with disabilities. These included Tata Institute of Fundamental Research (Mumbai), University of Allahabad, Guru Nanak Dev University (Amritsar), University of Rajasthan, Rabindra Bharati University (Kolkata), and Manipal Academy of Higher Education (Karnataka) among others. 31 Universities projected less than 5 students with disabilities, which included National Institute of Mental Health and Neuro Sciences (Bangalore), School of Planning and Architecture (Delhi), Indian Institute of Technology (Kanpur), Punjab Agricultural University (Ludhiana), North-Eastern Hill University (Shillong), and University of Pune. 23 Universities had more than 5 but less than 20 disabled students. These included Tata Institute of Social Sciences, Mumbai, Punjab University, Chandigarh, Indian Institute of Technology, Chennai, Roorkee, Mumbai, and G.B. Pant University of Agriculture \& Technology, Uttaranchal.

* While 112 Universities (94\%) mentioned that they gave admission to students with disabilities, only 24 (20\%) of them provided special equipment for the students with disabilities. Clearly, it was just by chance that the others had a few students with disabilities in their institutions.

* When given a chance to explain reasons for not admitting students with disabilities, very few Universities were forthcoming. Only 6 admitted to the lack of trained staff and only 5 admitted to lack of infrastructure.

* Out of the 119 respondent Universities, 47 Universities mentioned that they gave scholarships to students with disabilities and 29 gave financial assistance. It was clear from the minimal number of students with disabilities in these Universities that these facilities were being provided in general for all students and students with disabilities could get them by sheer chance. For example, though 73 Universities mentioned that they provided hostel facility for students with disabilities, it was unlikely that any hostel had even a single toilet/ room/ mess area accessible for a wheelchair user and it is lack of proper hostels and financial constraints that greatly limit the choices of students with disabilities to have HE.

* Only 50\% of the 119 Universities reported being aware of the UGC schemes and only 11 (9\%) Universities had received UGC grant under the schemes. The University Grants Commission initiated two schemes in 1998: one for the preparation of teachers for special education at the B. Ed. and M. Ed. levels and the other for the provision of facilities for promoting HE for students with disabilities.

* About $80 \%$ of the respondent institutions reported that students with disabilities were easily able to reach the classrooms, offices, toilets, auditorium, sports area, library, canteen, laboratories and the hostels. The institutions obviously did not understand the issue of access and were under the impression that all the places were accessible for all present and future students with disabilities.

\section{Various Challenges Faced by SWDs in Higher Education:-}

Regardless of many changes in country's educational acts, policies, schemes, approaches and the development of programs for students with disabilities, in recognition of the importance of higher education for individuals, families, and society at large, low enrolment and high dropout have been found. Low enrolment and high dropout can be understood as the result of inadequate accessibility of higher education institutions, lack of support, adverse social attitudes and social isolation, as well as low financial capacity (Foreman et al., 2001; Jung, 2003; Johnson, 2006; McKenzie \& Schweitzer, 2001; Mpofu \& Wilson, 2004). Among the supporting factors, studies have shown the importance of faculty's attitudes toward students with disabilities, their awareness of these students' needs, and their knowledge of the reasonable accommodations available. These attitudes influence success or failure of students with disabilities, and affect inclusion in higher education (Rao, 2004). Negative attitudes of faculty and administrative staff may prevent students, especially students with invisible disabilities, from disclosing their disabilities and from requesting accommodations they are entitled to (Jung, 2003; Johnson, 2006). Infrastructural 
barrier is another challenge which limits the students with disabilities from accessing higher education. Research claims that very few faculty members can understand the individual need of students with disabilities and show their willingness to change the material covered in the course to suit these students' learning needs. Most (82\%) of the students with disabilities indicated that faculty members needed to learn more about disabilities (Barazandeh, 2005; Kraska, 2003). In regard to academic achievements, studies have shown conflicting results. Some found the average grades among students with disabilities significantly is lower and the percentage of course drop-out or failures in courses is higher (Foreman, Dempsey, Robinson \& Manning, 2001). Students with disabilities reported a subjective feeling that they were not succeeding like other students, as well as difficulty in coping with the required investment during the study period (Foreman et al., 2001; McKenzie \& Schweitzer, 2001), and a sense of social isolation (Shevlin, Kenny \& McNeela, 2004).

\section{Factors Involved in the Success of SWDs in Higher Education: Supportive Reviews:-}

* Research reveals that support services have a direct effect on academic integration, and an indirect effect upon intent to stay in school for students with disabilities (English, 1993).

* Acceptance of disability is a significant predictor for either academic achievement or academic persistence of students with disabilities (Flowers, 1993).

* Research (Keim, 1996) reveals that there is a positive relationship between effective university accommodation and academic success of students with learning disabilities.

* Anderson (1993) surveyed 26 students with disabilities and 66 non-disabled students regarding social support and barriers to higher education. Results indicated that students with disabilities on average had more professionals within their personal support network. Both students with and without disabilities described social support network as important to successful adjustment to university. Students with disabilities expressed that the need for emotional support and ongoing adjustment to disability, which were not readily identified by the non-disabled students.

* The result of a study conducted by Allison (1994) shows that lack of social support (family, friends and teachers) is one of the important factors that contribute to drop outs of students with disabilities in higher education.

* In a qualitative study, Hurst (1991) studied the experiences of three small cohorts of students, whose disabilities affected their walking, as they attempted to secure places in various higher educational institutions. The interviews suggested that most of these students encountered negative discrimination when they tried to enter higher education.

* Denny and Carson (1994) found social behavior as the strongest factor in promoting higher education for students with disabilities. Researchers made recommendations to encourage acceptance and increase social contact for students with disabilities. These recommendations included, faculty modeling of positive behavior in interacting with students with disabilities and increased use of cooperative work in classrooms. Students with disabilities believed that decreasing physical barriers could increase social interaction by way of improved access to various university-wide activities.

* Based on the finding of his research Farbman (1983) concluded that the degree of autonomy afforded to professors by academic freedom may be detrimental to students with disabilities and preparing these students with advocacy and negotiation skills would best enhance their educational opportunities.

* In a study of faculty awareness about students with disabilities, Baggett (1994), found that the faculty lacked experience teaching students with disabilities, were unfamiliar with the various disability rights and laws, and were unfamiliar with the various university-wide services available to these students with disabilities. Among the disability groups, the faculty was more familiar with teaching learning disabilities than the other groups of disabilities.

* In an effort to understand the faculty attitudes and knowledge of disability laws, Benham (1995) found significant relationships between teaching experience in higher education and faculty attitudes toward students with disabilities. Faculty members with more teaching experience in higher education tended to have more positive attitudes toward students with disabilities. 


\section{Suggestions for Making Inclusive University:-}

To address the above discussed challenges experienced by students with disabilities and create an inclusive environment in university capable to meet the unique individual needs of students with or without disabilities the following suggestions can be made:-

* Keep in mind the rights of person with disabilities to access higher education in an inclusive and enabling environment the existing higher education policies, acts and schemes are be to evaluated, revised if needed and implemented in its true spirit in order to ensure quality, equity, and accessibility for students with disabilities in higher education

* Inclusive design of architecture and university environment does not seem to be understood by universities in India. Therefore, proper legislations guidelines have to be formed and responsibility should be given on each higher education institutions to be more proactive in supporting students with disabilities by creating barrier free inclusive and enabling environment for students with disabilities.

* Indian educational system lack adequate funding, training facilities, resources and effective special needs curriculum, content specific adequate teaching learning materials, and advanced technology integration; thus, most scholars, professors and instructors find it difficult to assist students with disabilities in attaining academic and social successes in higher education. Therefore, the governments should provide funds, resources, training to staffs which would help to promote an inclusive and enabling learning environment in university and ensure the development of students with disabilities.

* Structuring or designing teaching learning process innovatively to anticipate needs of students with disabilities.

* Academic adjustments or accommodations should be provided in many forms as needed by a particular disability. Some common academic accommodations include, but are not limited to:

$>$ Readers

$>$ Note takers

$>$ Interpreters

$>$ Accessible classroom location

$>$ Advance notice of assignments

$>$ Assistive technology and devices

$>$ Disabled friendly Lab or library

$>$ Trained (in disability) assistants at Lab or library

$>$ Open/closed captioned videos/films

$>$ Course or program modifications

$>$ Need based and flexible syllabus with multiple options

$>$ Document conversion (Braille, large print, tape, digitalization of text)

$>$ Exam modifications (e.g., extended time, alternative test formats and exams, quiet space for testing)

$>$ Ensuring universal design of learning (multiple means or ways of presentation, expression and engagement).

$>$ Using audio-visual materials and resources in the classroom- projectors, slides, videos, films, posters, etc, and any useful teaching-learning technology tools for instructional delivery.

* Teachers should be alert and attentive to student behaviors in classrooms- comments, giggles, questions, facial expressions. This could be a sign of some social/ learning problems or disability. These have to be addressed immediately after class in an interpersonal and respectful manner.

* Universities should set up campus-wide special assistance cell to look into the academic and social issues of students with disabilities right from their first day in school.

* Faculty members should be encouraged to take part in workshops, seminars, conferences, short-term training programmes on disability related issues and work more with students with developmental and learning disabilities and other groups to enhance their teaching competence and learn about learning needs and aspirations of students with disabilities.

* Providing support for students with disabilities who were not diagnosed before.

* Promoting social acceptance for students with disabilities among faculties and students without disabilities. Students without disabilities must be encouraged to work co-operatively with students with disabilities. In this context peer group teaching can be given due importance.

* Establishing equity and equal opportunity cell in every university with standard and obligatory guidelines for students with disabilities. Issues related to girl students with disabilities should be given due importance here. 


\section{Conclusion:-}

The importance of higher education in providing students with disabilities decent employment opportunities and social status is well documented. At a time of legislative endorsement of access to higher education, and of changes in attitudes resulting from the struggle for equal rights for people with disabilities, it is crucial to broaden knowledge and understanding of the broad perspective of needs, achievements and challenges of this group of students in higher education. Keeping this in mind, in the present paper, the author tries to address the various challenges which students with disabilities experience in higher education by promoting an inclusive learning environment in university or making inclusive university as inclusive education system in university strives to bring about greater participation, democracy, equity, equality and emancipation for all including students with disabilities.

\section{References:-}

1. Akoojee, S., \& Nkomo, M. (2007). Access and quality in South African higher education: The twin challenges of transformation. South African Journal of Higher Education, 21(3), 385-399.

2. Allison, L. S. (1994). Utilization of reasonable accommodations for university students with disabilities and their relationship to graduation rates. Unpublished Master's thesis, California State University.

3. Anderson, M. P. I. (1993). Social support and barriers to higher education: Experience of students with physical disabilities. Unpublished master's thesis, University of Alberta at Edmonton.

4. Armstrong, D., Armstrong, A. C., \& Spandagou, I. (2011). Inclusion: By choice or by chance? International Journal of Inclusive Education, 15(1), 29-39.

5. Baggett, D. (1994). A study of faculty awareness of students with disabilities. Washington, DC: EDRS.

6. Barazandeh, G. (2005). Attitudes toward disabilities and reasonable accommodation at the university. The Undergraduate Research Journal,7, 1-12.

7. Benham, N. E. (1995). Faculty attitudes and knowledge regarding specific disabilities and the Americans with Disabilities Act. Unpublished doctoral dissertation, University of Southern Mississippi.

8. Debram, C. C., \& C. H., Salzberg. (2005). A validated curriculum to provide training to faculty regarding students with disabilities in higher education. Journal of Postsecondary Education and Disability, 18(1), 49-62.

9. Debram, C. C., \& Salzberg, C. H. (2005). A validated curriculum to provide training to faculty regarding students with disabilities in higher education. Journal of Postsecondary Education and Disability, Vol.-18 (1), pp. 49-62.

10. Denny, G. S., \& Carson, E. K. (1994). Perceptions of campus climate for students with disabilities. Washington, DC: EDRS.

11. English, K. M. (1993). The role of support services in the integration and retention of college students who are hearing-impaired. Unpublished doctoral dissertation, Claremont Graduate School and San Diego State University.

12. Farbman, A. H. (1983). Case studies of university science faculty: Experiences with students with disabilities. Unpublished doctoral dissertation, George Washington University.

13. Ferni, T., \& Henning, M. (2006). From a disabling world to a new vision. In M., Adams \& S., Brown (Eds.), towards inclusive learning in higher education, edited by, (pp. 23-31). London: Routledge.

14. Flowers, C. R. (1993). Academic achievement, academic persistence and acceptance of disability among students with disabilities at a higher institution. Unpublished doctoral dissertation, Southern Illinois University at Carbondale.

15. Foreman, P., Dempsey, I., Robinson, G., \& Manning, E., (2001). Characteristics, academic, and post-university outcomes of students with a disability at the University of Newcastle. Higher Education Research \& Development, 20(3), 313-325.

16. Foreman, P., Dempsey, I., Robinson, G., \& Manning, E., (2001). Characteristics, academic, and post-university outcomes of students with a disability at the University of Newcastle. Higher Education Research \& Development, 20(3), 313-325.

17. Fuller, M., Bradley, A., \& Healey, M. (2004). Incorporating disabled students within an inclusive higher education environment. Disability \& Society, 19 (5), 455-468. doi: 10.1080/0968759042000235307.

18. Hurst, H. A. (1991). Access to higher education and people with disabilities: Individual and institutional perspectives. Unpublished doctoral dissertation, University of Lancaster, United Kingdom.

19. Johnson, A. L. (2006). Students with disabilities in postsecondary education: Barriers to Success and implication to professionals. Vistas Online. Retrieved from: http://counselingoutfitters. com/vistas2006, on 11.11.2015. 
20. Jung, K. E. (2003). Chronic illness and academic accommodation: Meeting disabled; Unique needs, and preserving the institutional order of the university. Journal of Sociology and Social Welfare, 30(1), 91-112.

21. Keim, J. (1996). Academic success and university accommodation for learning disabilities: is there a relationship? Journal of College Student Development, 37(5), 502-509.

22. Kraska, M. (2003). Postsecondary students with disabilities and perception of faculty Members. The Journal for Vocational Special Needs Education, 25(2), 11-19.

23. Lambe, J. (2011). Pre-service education and attitudes towards inclusion: The role of the teacher educator within a permeated teaching model. International Journal of Inclusive Education, 159(9), 975-999.

24. McKenzie, K., \& Schweitzer, R., (2001). Who succeeds at university? Factors predicting academic performance in first year Australian University students. Higher Education Research \& Development, 20(1), 21-23.

25. Mpofu, E. \& Wilson, K. (2004). Opportunity structure and transition practices with students with disabilities: The role of family, culture, and community. Journal of Applied Rehabilitation Counseling, 35(2), 9-16.

26. Rao, S. (2004). Faculty attitudes and students with disabilities in higher education - a literature reviews. College Student Journal, 38(2), 191-198.

27. Shevlin, M., Kenny, M., \& McNeela, E. (2004). Participation in higher education for students with disabilities: an Irish perspective. Disability \& Society, 19(1), 15-30.

28. Tomlinson, J. (1996). The Tomlinson report-inclusive learning. Further education funding council learning difficulties and/or disabilities committee (FEFCE). Retrieved http://dera.ioe.ac.uk/15072/1/inclusive\%20learning-summary.pdf, on 11.11.2015.

29. UNESCO. (1994).The Salamanca Statement and Framework for Action on Special Needs Education. Adopted by the World Conference on Special Needs Education: Access and Quality, held in Salamanca, Spain, 7$10^{\text {th }}$ June, 1994.

30. UNESCO. (1998). World conference on Higher Education Higher Education in the Twenty-First Century Vision and Action. UNESCO: Paris.

31. United Nations (UN). (2006). Convention on the Rights of Persons with Disabilities and Optional Protocol. Retrieved from: http://www.un.org/disabilities/documents/convention /convoptprot-e.pdf, on 10.10.2015.

32. World Health Organization (WHO). (2001). International classification of functioning, disability and health. Geneva: WHO. 